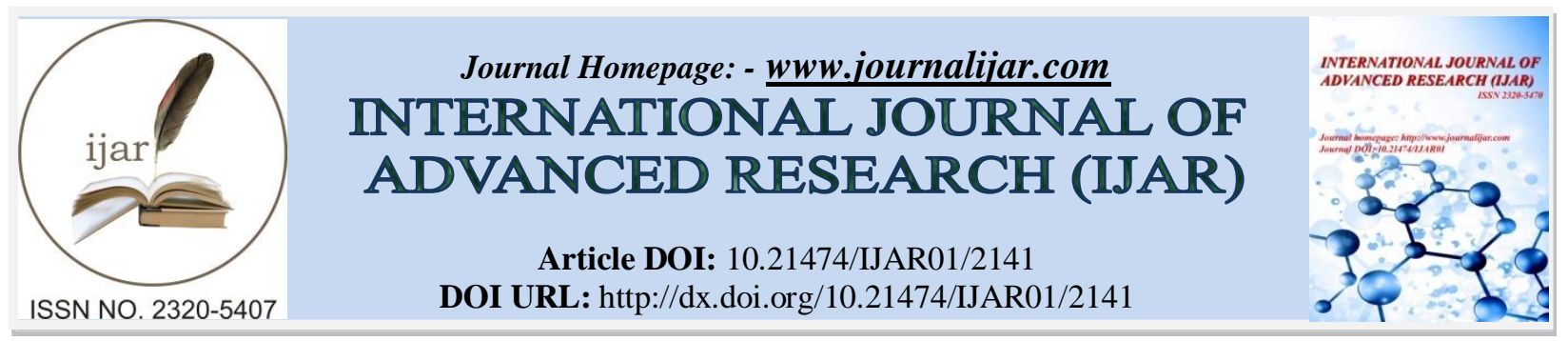

RESEARCH ARTICLE

\title{
HETEROSIS STUDIES FOR YIELD ANDITS ATTRIBUTING TRAITS IN TOMATO UNDER MID-HILL CONDITIONS OF GARHWAL.
}

\author{
Pawan Kumar ${ }^{1}$, Ajaya Paliwal ${ }^{2}$, Dinesh Tiwari ${ }^{3}$, Sandeep Upadhyay ${ }^{4}$ and Pankaj Bahuguna ${ }^{5}$. \\ 1. Department of Vegetable Science, College of Horticulture, VCSHUUHF, Bharsar. \\ 2. Department of Crop Improvement, College of Horticulture, VCSHUUHF, Bharsar. \\ 3. Department of MAP, College of Horticulture, VCSHUUHF, Bharsar. \\ 4. Department of Natural Resource Management, College of Horticulture, VCSHUUHF, Bharsar. \\ 5. Department of Basic Sciences \& Humanities, College of Horticulture, VCSHUUHF, Bharsar.
}

\section{Manuscript Info}

Manuscript History

Received: 25 September 2016

Final Accepted: 27 October 2016

Published: November 2016

Key words:-

Tomato, Heterosis, Yield,

Heterobeltiosis, Hills

\section{Abstract}

Tomato (Solanum lycopersicum L.), a self-pollinated vegetablecrop of solanaceae family, ranks second in importance after potato but tops the list of processed vegetables. Heterosis breeding is reliable and quick approach to gain maximum crop improvement. Six diverse tomato cultivars/ lines viz, Arka Saurabh, Arka Abha, Arka Meghali, Punjab Chhuhara, Best of All and Sioux, selected on the basis of high yield coupled with high quality, were crossed in a half diallel fashion to obtain fifteen cross combinations. Arka Meghali x Punjab Chhuhara found to be the best cross combination which have significant heterosis of all three types for vitals yield attributing traits, i.e. number of fruits per cluster and number of fruit clusters per plant in spite of that for number of fruits per plant didn't have significant heterotic results in favourable direction. Hybrids have reported greater plant heights as compared to mid parents.Most of the crosses manifested highly significant heterosis for fruit length and fruit breadth that reflect that hybrids have better chance of having bigger fruits. For average fruit weight, Arka Abha x Arka Meghali, Arka Meghali x Punjab Chhuhara proved to be the best hybrids which has expressed significant positive results for both types of heterosis. Overall, top three cross combinations for fruit yield per plant as per their per se performance, Arka Abha x Punjab Chhuhara, Arka Meghali x Punjab Chhuhara, Punjab Chhuhara $x$ Best of All came out to be expressing significantly positive standard heterosis. Present investigation found sufficient heterotic potential in the parental cultivars that can be utilized to develop improved recombinant or hybrids genotypes.

Copy Right, IJAR, 2016,. All rights reserved.

\section{Introduction:-}

Tomato (Solanum lycopersicumL.) $2 \mathrm{n}=2 \mathrm{x}=24$ is one of the most important solanaceousvegetable crop grown throughout the world. It was originated in Central and South America (Vavilov, 1951). In the world, it ranks second in importance after potato but tops the list of processed vegetables (Chaudhary, 1996). It is a very good source of income for small and marginal farmers and also contributes to the nutrition of the consumer (Singh et al., 2010). The 
ripe fruits are taken as raw or made into salads, soups, preserve, pickles, ketchup, puree, paste and many other products (Chadha, 2001).

Tomato is grown as autumn-winter, winter and spring-summer crop in many parts of country but owing to high temperature and rains, tomato cannot be grown commercially in the North Indian plains from May to October. In India, it occupied an area of 8.82 lakh hectares with a production of 18.73 million metric tonnes with an average productivity of 21.23 metric tonnes per hectare. It occupies second position among the vegetable crops in terms of production after potato. Uttarakhand is one of the tomato growing state covering an area of 9.08 thousand hectare with a production of 113.65 thousand metric tonnes with an average productivity of 12.51 metric tonnes per hectares (NHB 2013-14). The productivity level of the state is much lower to nation which further raised the need to develop location specific superior cultivars adapted for the region to meet the ever-increasing demand for this vegetable in fresh market and processing industries, it is imperative to develop such hybrids which are good in both yield and quality of the produce.

Heterosis in tomato was first observed by Hedrick and Booth (1907) for higher yield and more number of fruits per plant. Subsequently, heterosis for yield and its component traits has been demonstrated by many workers (Wellington, 1912; Burdick, 1954; Daskalef et al., 1967). Larson and Currence (1944) observed that average yield of all tested $F_{1}$ hybrids was $39 \%$ above the average yield of the parental lines. Power (1945) found that the mean value of total yield of red fruits of the hybrid surpassed by $60 \%$ of the mean value of the parental lines. Heterosis manifests in tomato in form of greater vigour, faster growth and development, earliness in maturity, increased productivity and higher levels of resistance to biotic and abiotic stresses.

Identification and selection of potential parental lines is required, which can be used in any hybridization programme to produce genetically improved and potentially rewarding germplasm by assembling fixable gene effects in a homozygous line. Exploitation of heterosis is primarily dependent on the screening and selection of available germplasm that could produce better combinations of important agronomic characters. The present study was under taken to estimate the extent of heterosis available in yield and its attributing traits.

\section{Materials and methods:-}

Six diverse tomato cultivars/lines viz, Arka Saurabh, Arka Abha, Arka Meghali, Punjab Chhuhara, Best of All and Sioux were selected on the basis of high yield coupled with high quality, and crossed in a half-diallel fashion to obtain fifteen cross combinations. The seedlings of parents were raised in November, 2013 and further transplanted in polyhouse to attempt crossing and generate F1. The seeds of crosses were harvested in April-June, 2014. The F1 seeds along with parents and two check hybrid varieties TS-15 and HYB-Roop-666 (Both commercial F1 hybrids from Ocean Crop Sciences) were planted during August, 2014 for their evaluation and generation of data. Two checks were taken to get maximum accuracy in estimation of heterosis which is commercially utilizable. The experiment was laid out in Randomized Complete Block Design (RCBD) with three replications. The seedlings were raised in August-2014 and transplanting of each entry in the block was done on $25^{\text {th }}$ August-2014. There were twelve plants of each entry in each replication in a plot of $1.8 \times 1.8 \mathrm{~m}^{2}$ with a spacing of $60 \mathrm{~cm} \mathrm{x} 45 \mathrm{~cm}$. The standard cultural practices were followed to raise the tomato crop. Analysis of variance (ANOVA) was performed as explained by Gomez and Gomez (1983) while the heterosis was analysed and tested for significance as explained by Nadarajan \& Gunasekaran (2012).

\section{Result and Discussion:-}

The analysis of variance for all the traits under study showed significant differences among parents and crosses. Magnitude of heterosis over mid parent and better parent of fifteen F1 hybrids has been presented character-wise in Table 1-2. The results obtained for different traits are described below: 
Table 1:- Heterotic response for various horticultural traits

\begin{tabular}{|c|c|c|c|c|c|c|c|c|}
\hline \multirow[t]{2}{*}{ Cross } & \multicolumn{2}{|c|}{$\begin{array}{l}\text { Number of fruits } \\
\text { per plant }\end{array}$} & \multicolumn{2}{|c|}{$\begin{array}{l}\text { Number of fruits } \\
\text { per cluster }\end{array}$} & \multicolumn{2}{|c|}{$\begin{array}{l}\text { Number of fruit } \\
\text { cluster per plant }\end{array}$} & \multicolumn{2}{|c|}{$\begin{array}{l}\text { Plant height at last } \\
\text { harvest } \\
\text { (cm) }\end{array}$} \\
\hline & MP & BP & MP & BP & MP & BP & MP & BP \\
\hline $\begin{array}{l}\text { Arka Saurabh x Arka } \\
\text { Abha }\end{array}$ & -5.26 & -9.52 & 2.67 & -3.49 & $14.00 *$ & $12.11 *$ & 11.68 & 11.23 \\
\hline $\begin{array}{l}\text { Arka Saurabh x Arka } \\
\text { Meghali }\end{array}$ & 3.07 & 2.78 & $-6.54 *$ & $-14.22 *$ & $16.94 *$ & $16.60^{*}$ & $22.46^{*}$ & $20.72 *$ \\
\hline $\begin{array}{l}\text { Arka Saurabh x Punjab } \\
\text { Chhuhara }\end{array}$ & $17.14^{*}$ & $11.45^{*}$ & 0.04 & -2.42 & $23.57 *$ & $14.61 *$ & $44.47 *$ & $35.88^{*}$ \\
\hline $\begin{array}{l}\text { Arka Saurabh x Best } \\
\text { of All }\end{array}$ & $12.50 *$ & 4.76 & $8.99 *$ & 0.08 & $26.24 *$ & $25.84 *$ & -2.09 & -8.70 \\
\hline Arka Saurabh x Sioux & -4.42 & -4.76 & $11.12^{*}$ & 3.40 & -9.03 & -9.94 & $14.04 *$ & 6.31 \\
\hline $\begin{array}{lll}\text { Arka Abha } & \mathrm{x} & \text { Arka } \\
\text { Meghali } & & \end{array}$ & -7.18 & $-11.57^{*}$ & $14.20 *$ & $11.32 *$ & -3.92 & -5.76 & $15.08^{*}$ & 13.00 \\
\hline $\begin{array}{l}\text { Arka Abha x Punjab } \\
\text { Chhuhara }\end{array}$ & 7.19 & 6.77 & -2.02 & $-10.04 *$ & $11.57^{*}$ & 1.92 & $21.01 *$ & 14.34 \\
\hline $\begin{array}{l}\text { Arka Abha x Best of } \\
\text { All }\end{array}$ & 2.88 & 0.17 & -0.64 & -3.09 & 1.96 & 0 & $51.24 *$ & $40.50 *$ \\
\hline Arka Abha x Sioux & -7.50 & $-11.37 *$ & 0.68 & -0.38 & $25.00 *$ & $21.73^{*}$ & $17.86^{*}$ & 10.29 \\
\hline $\begin{array}{l}\text { Arka Meghali x Punjab } \\
\text { Chhuhara }\end{array}$ & 4.25 & -1.05 & -3.24 & $-13.19 *$ & $42.65^{*}$ & $32.66^{*}$ & $19.15^{*}$ & 10.66 \\
\hline $\begin{array}{l}\text { Arka Meghali x Best } \\
\text { of All }\end{array}$ & 2.17 & -5.10 & 6.67 & 6.61 & 7.33 & 7.33 & 0.74 & -4.77 \\
\hline Arka Meghali x Sioux & -4.32 & -4.92 & 5.22 & 3.65 & $10.73 *$ & 10.00 & $21.22 *$ & 11.52 \\
\hline $\begin{array}{ll}\text { Punjab Chhuhara } & \mathrm{x} \\
\text { Best of All } & \end{array}$ & $18.48^{*}$ & $15.82 *$ & 6.08 & -4.77 & $14.69 *$ & 6.60 & $28.83 *$ & $13.59 *$ \\
\hline $\begin{array}{lll}\text { Punjab } & \text { Chhuhara } & \mathrm{x} \\
\text { Sioux } & & \\
\end{array}$ & -3.62 & -7.99 & $11.30 *$ & 1.21 & $16.24 *$ & 8.82 & 13.06 & 11.91 \\
\hline Best of All x Sioux & 6.46 & -0.53 & $13.89 *$ & $12.26^{*}$ & 2.01 & 1.33 & $26.02 *$ & 10.22 \\
\hline $\mathrm{SE}(\mathrm{d}) \pm$ & 1.79 & 2.07 & 0.11 & 0.13 & 0.46 & 0.53 & 8.40 & 9.70 \\
\hline
\end{tabular}

\section{Number of Fruits per Plant:-}

Number of fruits per plant is the most important component trait, which is directly related with increased fruit yield per plant. The heterosis over mid parent ranged from -7.50 to 18.48 per cent, with maximum in Punjab Chhuhara $\mathrm{x}$ Best of All. Out of fifteen cross combinations, three crossesviz, Punjab Chhuhara x Best of All (18.48\%) Arka Saurabh x Punjab Chhuhara (17.14 \%) and Arka Saurabh x Best of All (12.50 \%) exhibited significant positive heterosis over mid parent for this trait.The heterosis over better parent ranged from -11.57 to 15.82 percent, with maximum in Punjab Chhuhara x Best of All. Only two crossesviz, Punjab Chhuhara x Best of All (15.82 \%) and Arka Saurabh x Punjab Chhuhara $(11.45 \%)$ exhibited significant positive heterosis over better parent for this trait.

Out of fifteen cross combinations, two crossesviz, Arka Saurabh x Punjab Chhuhara and Punjab Chhuhara x Best of All resulted in significant positive heterosis over both mid and better parent. Positive heterosis over better parent for this trait has also been reported by Ahmed et al. (1988), Dev et al. (1994), Singh et al. (1995), Dharmatti et al.(1997), Srivastava et al. (1998), Gunasekera and Parera (1999), Bhatt et al.( 2001), Thakur et al.(2004), Singh et al.(2005a), Premalakshme et al. (2005), Mirshamssi et al.( 2006), Hannan et al. (2007), Rani and Veeraragavathatham (2008), Kumar et al. (2009), Kumari et al. (2010), Kumari and Sharma (2011), Ahmed et al. (2011).

\section{Number of fruits per cluster:-}

Among the fifteen cross combinations, six crosses showed significant positive heterosis over mid parent. The heterosis over mid parent ranges from -6.54 to 14.20 percent, minimum being in Arka Saurabh x Arka Meghali and maximum in Arka Abha x Arka Meghali. The significant positive heterosis was observed in the crossesviz, Arka 
Abha x Arka Meghali (14.20 \%), Best of All x Sioux (13.89\%), Punjab Chhuhara x Sioux (11.30\%), Arka Saurabh x Sioux (11.12\%) and Arka Saurabh x Best of All (8.99\%)

The heterosis over better parent ranged from $-14.22 \%$ (Arka Saurabh x Arka Meghali) to $12.26 \%$ (Best of All x Sioux). Three cross combinationsviz, Best of All x Sioux (12.26\%) and Arka Abha x Arka Meghali (11.32\%) showed significant positive heterosis over better parent.

Average number of fruits per cluster in these studies have five cross combinations viz, Arka Saurabh $\mathrm{x}$ Best of All, Arka Saurabh x Sioux, Arka Abha x Arka Meghali, Punjab Chhuhara x Sioux and Best of All x Sioux with significant positive heterosis over mid parent while only two cross combinations viz, Arka Abha x Arka Meghali and Best of All x Sioux showed significant positive heterosis over better parent.

Positive heterosis over better parent for this trait was also reported by many workers like Dev et al. (1994), Pujari and Kale (1994), Thakur et al. (2004), Kumar et al. (2009), Gul et al. (2010), Kumari et al. (2010), Kumari and Sharma (2011) and Ahmed et al. (2011).

Number of fruits per cluster showed significant positive heterobeltiosis and standard heterosis. These results are on line with Prashanth (2004), Kulkarni (2003), Joshi and Thakur (2003) and Sharma and Thakur (2008).

\section{Number of fruit clusters per plant:-}

The heterosis over the mid parent ranges from $-9.03 \%$ (Arka Saurabh x Sioux) to 42.65\% (Arka Meghali x Punjab Chhuhara). Out of the fifteen crosses fourteen showed positive mid parent heterosis out of them only ten were significant.

The range of heterobeltiosis for number of fruit clusters per plant varied from $-9.94 \%$ (Arka Saurabh x Sioux) to $32.66 \%$ (Arka Meghali x Punjab Chhuhara) and six cross combinations resulted in significantly positive heterobeltiosis.

For average number of fruits cluster per plant, Arka Meghali x Punjab Chhuhara has positively significant values for both types of heterosis. Similar observations were also recorded by Sajjan (2001), Kulkarni (2003) and Duhan et al (2005) and Sekhar et al (2010).

\section{Plant height at last harvest (cm):-}

Taller plant is considered to be desirable because it leads to more number of branches and ultimately result in increased productivity. The relative heterosis effects ranges from -2.09\% (Arka Saurabh x Best of All) to 44.47\% (Arka Saurabh x Punjab Chhuhara) for plant height at last harvest. Out of fifteen cross combinations, fourteen crosses showed positive heterosis over mid parent, out of which ten crosses showed significant positive heterosis.

Further, heterosis over better parent for plant height at last harvest ranged from $-8.70 \%$ (Arka Saurabh x Best of All) to $35.99 \%$ (Arka Saurabh x Punjab Chhuhara). The only three cross combinations viz, Arka Saurabh x Punjab Chhuhara (35.99\%), Arka Saurabh x Arka Meghali (20.72\%) and Arka Abha x Best of All (19.19\%) revealed significant positive heterosis over better parent.

Ten and three crosses out of fifteen, showed significantly positive heterosis over mid and better parents, respectively. Significant positive heterobeltiosis for this trait has also been reported by Dev et al., (1994), Srivastava et al., (1998), Thakur et al., (2004), Mirshamssi et al., (2006); Rani and Veeraragavathatham, (2008), Sharma and Thakur (2008), Kumari et al. (2010), Singh and Asati (2011), Kumari and Sharma (2011) and Ahmed et al (2011). 
Table 2:- Heterotic response for various horticultural traits.

\begin{tabular}{|c|c|c|c|c|c|c|c|c|}
\hline \multirow[t]{2}{*}{ Cross } & \multicolumn{2}{|c|}{$\begin{array}{l}\text { Fruit length } \\
\text { (cm) }\end{array}$} & \multicolumn{2}{|c|}{$\begin{array}{l}\text { Fruit breadth } \\
\text { (cm) }\end{array}$} & \multicolumn{2}{|c|}{$\begin{array}{ll}\begin{array}{l}\text { Average } \\
\text { weight }(\mathrm{g})\end{array} & \text { fruit } \\
\end{array}$} & \multicolumn{2}{|c|}{$\begin{array}{l}\text { Fruit yield per } \\
\text { plant }(\mathrm{g})\end{array}$} \\
\hline & MP & $\mathbf{B P}$ & MP & $\mathbf{B P}$ & MP & BP & MP & BP \\
\hline $\begin{array}{l}\text { Arka Saurabh x Arka } \\
\text { Abha }\end{array}$ & 6.05 & 5.71 & -1.09 & -5.80 & 7.90 & 5.05 & 1.87 & -0.40 \\
\hline $\begin{array}{l}\text { Arka Saurabh x Arka } \\
\text { Meghali }\end{array}$ & $11.63 *$ & 8.16 & $11.66^{*}$ & $7.85^{*}$ & 2.85 & -1.23 & 8.26 & 4.37 \\
\hline $\begin{array}{l}\text { Arka Saurabh x Punjab } \\
\text { Chhuhara }\end{array}$ & $10.06^{*}$ & -4.31 & $15.37 *$ & -1.43 & -7.06 & -9.47 & 10.57 & 3.83 \\
\hline $\begin{array}{l}\text { Arka Saurabh x Best } \\
\text { of All }\end{array}$ & 4.94 & 3.79 & 0.43 & $-5.53 *$ & 2.62 & 1.37 & $13.64 *$ & 4.55 \\
\hline Arka Saurabh x Sioux & 1.92 & 1.33 & $15.44 *$ & $10.24 *$ & 9.19 & 8.52 & 4.03 & 3.28 \\
\hline $\begin{array}{l}\text { Arka Abha } \mathrm{x} \text { Arka } \\
\text { Meghali }\end{array}$ & -1.58 & -4.34 & $-3.93^{*}$ & $-11.47^{*}$ & $29.95^{*}$ & $21.63^{*}$ & $22.58^{*}$ & $20.83^{*}$ \\
\hline $\begin{array}{l}\text { Arka Abha x Punjab } \\
\text { Chhuhara }\end{array}$ & 4.70 & $-9.23^{*}$ & $7.28^{*}$ & $-11.97^{*}$ & $16.85^{*}$ & 10.90 & $34.67 *$ & $29.23^{*}$ \\
\hline $\begin{array}{l}\text { Arka Abha } x \text { Best of } \\
\text { All }\end{array}$ & 7.58 & 6.75 & $4.56^{*}$ & $-6.04 *$ & $17.49^{*}$ & 13.04 & $21.70^{*}$ & 14.37 \\
\hline Arka Abha x Sioux & -1.80 & -2.67 & -0.16 & $-8.99 *$ & 11.20 & 7.61 & 8.72 & 7.06 \\
\hline $\begin{array}{l}\text { Arka Meghali x Punjab } \\
\text { Chhuhara }\end{array}$ & 1.66 & $-13.96^{*}$ & $18.54^{*}$ & 4.34 & $28.57^{*}$ & $26.70^{*}$ & $34.62 *$ & $30.99 *$ \\
\hline $\begin{array}{l}\text { Arka Meghali x Best } \\
\text { of All }\end{array}$ & $13.75^{*}$ & $11.47^{*}$ & $7.44^{*}$ & 4.51 & 2.87 & -0.03 & $23.32 *$ & $17.47 *$ \\
\hline Arka Meghali x Sioux & 2.26 & -1.45 & $6.58^{*}$ & $5.33 *$ & 12.71 & 8.87 & -8.45 & -11.11 \\
\hline $\begin{array}{l}\text { Punjab Chhuhara } \mathrm{x} \\
\text { Best of All }\end{array}$ & -3.86 & $-17.20^{*}$ & $8.91 *$ & -1.75 & 12.75 & 11.16 & $34.73^{*}$ & $31.82 *$ \\
\hline $\begin{array}{lll}\text { Punjab } & \text { Chhuhara } & \mathrm{x} \\
\text { Sioux } & & \end{array}$ & -3.39 & $-15.61 *$ & $21.49 *$ & 8.05 & -5.00 & -6.90 & -11.63 & $-16.44^{*}$ \\
\hline Best of All x Sioux & 1.98 & 0.30 & 2.17 & 0.56 & -1.98 & -2.58 & 9.05 & 1.01 \\
\hline $\mathrm{SE}(\mathrm{d}) \pm$ & 1.58 & 1.83 & 1.00 & 1.16 & 3.56 & 4.11 & 173.30 & 200.11 \\
\hline
\end{tabular}

* Significant at $5 \%$ level

Fruit length (mm):-

Fruit length is as an important component which directly contribute to yield in tomato. For fruit length (mm),only three crosses out of the fifteen cross combinationsviz, Arka Meghali x Best of All (13.75\%), Arka Saurabh x Arka Meghali (11.63\%) and Arka Saurabh x Punjab Chhuhara (10.06\%) showed significantly positive mid parent heterosis. It ranges from $-3.86 \%$ (Punjab Chhuhara x Best of All) to $13.75 \%$ (Arka Meghali x Best of All).

The heterosis over better parent for fruit length (mm)ranged from $-17.20 \%$ (Punjab Chhuhara $\mathrm{x}$ Best of All) to 11.47\% (Arka Meghali x Best of All). Out of fifteen crosses, only one cross combination viz, Arka Meghali x Best of All (11.47\%) resulted in significantly positive heterosis over the better parent.

In the present studies, Arka Meghali x Best of All crossed expressed its superiority for both types ofheterosis. Significant positive heterosis over mid and better parent was also reported by Mahendrakar. (2004) Gul et al. (2010), Islam et al. (2012) and Singh et al. (2012).

\section{Fruit breadth (mm):-}

Fruit breadth also has been identified as an important yield component that have direct and positive contribution to yield in tomato. The heterosis over mid parent ranges from -3.93\% (Arka Abha x Arka Meghali) to 21.49\% (Punjab Chhuhara x Sioux) for fruit breath. Out of the fifteen cross combinations, ten crosses expressed significantly better mid parent heterosis.

The heterosis over better parent for fruit breath (mm)ranged from $-11.97 \%$ (Arka Abha x Punjab Chhuhara ) to 10.24\% (Arka Saurabh x Sioux). Out of fifteen crosses, only four cross combinationviz, Arka Saurabh x Sioux 
(10.24\%), Punjab Chhuhara x Sioux (8.05\%), Arka Saurabh x Arka Meghali (7.85\%) and Arka Meghali x Sioux $(5.33 \%)$ resulted in significant positive heterosis over the better parent.

Out of fifteen crosses, ten crosses for relative, four crosses for better and thirteen crosses for standard heterosis revealed significant positive values.Mahendrakar (2004) Baishya et al. (2001), Gul et al. (2010) and Islam et al. (2012) and Singh et al. (2012) also reported heterosis on fruit breadth in tomato.

\section{Average fruits weight $(\mathrm{g})$ :-}

Out of fifteen cross combinations, thirteen crosses showed positive relative heterosis and out of them, only four crosses showed significant positive heterosis over mid parent for average fruit weight $(\mathrm{g})$. The heterosis over mid parent ranges from $-7.06 \%$ (Arka Saurabh x Punjab Chhuhara) to 29.95\% (Arka Abha x Arka Meghali). The significant positive heterosis over mid parent was observed in the cross Arka Abha x Arka Meghali (29.95\%), Arka Meghali x Punjab Chhuhara (28.57\%), Arka Abha x Best of All (17.49\%) and Arka Abha x Punjab Chhuhara $(16.85 \%)$.

The heterosis over better parent ranged from -9.47 to 26.70 percent, being lowest in Arka Saurabh x Punjab Chhuhara and highest in Arka Meghali x Punjab Chhuhara. The maximum significant positive heterobeltiosis was exhibited by the cross Arka Meghali x Punjab Chhuhara (26.70\%) and Arka Abha x Arka Meghali (21.63\%). Among the fifteen cross combinations, eleven crosses showed positive heterobeltiosis and out of them only two crosses showed significant positive heterobeltiosis for average fruit weight $(\mathrm{g})$.

Average fruit weight is also a direct contributing trait to yield. The significant relative heterotic effects were observed in four crossesviz, Arka Abha x Arka Meghali, Arka Abha x Punjab Chhuhara, Arka Abha x Best of All and Arka Meghali x Punjab Chhuhara, which was also proved again in two cross combinations, for heterobeltiosis e.g. Arka Abha x Arka Meghali and Arka Meghali x Punjab Chhuhara.

For average fruit weight expression of significant positive heterosis over mid and better parent corroborate with the findings of Singh et al. 2008, Ahmed et al. (1988), Pujari and Kale (1994), Dev et al. (1994), Singh et al. (1995), Gunasekera and Parera (1999), Tiwari and Lal (2004), Thakur et al. (2004), Premalakshme et al. (2005), Anita et al. (2005), Singh et al. (2005a), Mirshamssi et al.(2006), Hannan et al.(2007a), Rani and Veeraragavathatham (2008), Kumar et al. (2009),Kumari et al. (2010), Gul et al. (2010), Ahmed et al. (2011), and Kumari and Sharma (2011).

\section{Fruit yield per plant (g):-}

The ultimate goal of any breeding programme is target to achieve maximization of yield. The range of heterosis over mid parent for yield per plant varied from -11.63\% (Punjab Chhuhara x Sioux) to 34.73\% (Punjab Chhuhara x Best of All). Over all, seven cross combinations resulted in significant positive heterosis over mid parent.

The range of heterobeltiosis for yield per plant varied from $-16.44 \%$ (Punjab Chhuhara x Sioux) to $31.82 \%$ (Punjab Chhuhara $x$ Best of All). Out of fifteen cross combinations, five crosses viz, Punjab Chhuhara x Sioux (31.82\%), Arka Meghali x Punjab Chhuhara (30.99\%), Arka Abha x Punjab Chhuhara (29.23\%), Arka Abha x Arka Meghali (20.83\%) and Arka Meghali x Best of All (17.47\%) resulted in significant positive heterosis over better parent.

In the present studies, among the fifteen cross combinations, five crossesviz, Arka Abha $\mathrm{x}$ Arka Meghali, Arka Abha x Punjab Chhuhara, Arka Meghali x Punjab Chhuhara, Arka Meghali x Best of All and Punjab Chhuhara x Best of All resulted in significant positive heterosis over mid and better parent. Positive heterosis over both mid and better parent for fruit yield per plant has also been reported by Bhatt et al.(2001), Sharma et al.(2001), Chaudhary and Malhotra (2001), Fageria et al. (2001), Thakur et al. (2004), Tiwari and Lal (2004), Mahendrakar et al. (2005), Premalakshme et al. (2005), Singh et al. (2005a), Anita et al. (2005) Mirshamssi et al. (2006), Hannan et al.(2007a), Rani and Veeraragavathatham (2008), Sharma and Thakur (2008), Kumar et al.(2009), Gul et al. (2010), Kumari et al. (2010), Kumari and Sharma (2011), Singh and Shastry (2011), Ahmad et al.(2011).

\section{Conclusion:-}

Top three cross combinations for fruit yield per plant as per their per se performance, Arka Abha x Punjab Chhuhara, Arka Meghali x Punjab Chhuhara, Punjab Chhuhara x Best of All came out to be expressing significantly positive heterosis. For average fruit weight, Arka Abha x Arka Meghali, Arka Meghali x Punjab Chhuhara proved to be the best hybrids which has expressed significant positive results for both types of heterosis. Arka Meghali $\mathrm{x}$ 
Punjab Chhuhara found to be the best cross combination which have significant favourable heterosis, of both the types, for vitals yield attributing traits i.e. number of fruits per cluster and number of fruit clusters per plant.Heterosis potential of the parents used in the selection further promote their use for yield improvement in tomato.

\section{Acknowledgement:-}

The authors acknowledges the support provided by the Dean of the College Prof. BP Nautiyal to smoothly carry out the research work along with the cooperation and technical guidance provided by OIC-Vegetable Science and the others.

\section{References:-}

1. Ahmed S., Quamruzzaman A.K.M. and Islam M.R., Estimate of heterosis in tomato (Solanum lycopersicum L.). Bangladesh Journal of Agricultural Research 36(3): 2011, 521-527.

2. Ahmed S.U., Saha H.K. and Sharufudin A.F.M. (1988). Studies on heterosis and correlation in tomato. Thailand Journal of Agriculture 21(2):117-123.

3. Baishya K.C., Syamal M.M. and Singh K.P. (2001). Heterosis studies in tomato (Lycopersicon esculentum Mill.). Vegetable Science 28: 168-169.

4. Burdick A. (1954). Genetics of Heterosis for earliness in the tomato. Genetics 39: 488-505.

5. Chadha K.L. (2001). Handbook of Horticulture. ICAR publication pp. 8.

6. Chaudhary B. (1996). Exploitation of heterosis in tomato yield and components. South Indian Horticulture 49: 59-85.

7. Daskalef C.H.M., Yordanov and Ognyanovo A. (1967). Heterosis in tomatoes. Academy press Sofia 180p

8. Dev H., Rattan R.S. and Thakur M.C. (1994). Heterosis in tomato (Lycopersicon esculentum Mill.). The Horticultural Journal 7(2):125-132.

9. Duhan D., Partap P.S., Rana M.K. and Dudi B.S. (2005). Combining ability study for growth and yield charecters in tomato. Haryana Journal of horticultural Sciences 34(1-2):128-134.

10. Gomez K.A., and Gomez A.A. (1983). Statistical procedures for agricultural research. John Wiley and Sons Inc., New York. p. 357-427.

11. Gul R., Hidayat-Ur-R., Khalil I.H., Shah M.A. and Ghafoor A. (2010). Heterosis for flower and fruit traits in tomato (Lycopersicon escuantum Mill). African Journal of Biotecnology 9(27): 4144-4151.

12. Hannan M.M., Ahmed M.B., Roy U.K., Razvy M.A., Haydar A., Rahman M.A., Islam M.A. and Islam R. (2007). Heterosis, Combining Ability and Genetics for Brix\%, Days to First Fruit Ripening and Yield in Tomato (Lycopersicon esculentum Mill.). Middle-East Journal of Scientific Research 2(3-4): 128-131.

13. Hedrick U.P. and Booth N. (1907). Mendelian characters in tomato. Proceedings of American Society of Horticultural Sciences 5: 19-24.

14. Islam M.R., Ahmad S. and Rahman M.M. (2012). Heterosis and qualitative attributes in winter tomato (Solanum lycopersicum L.). hybrids. Bangladesh Journal of Agricultural Research 37(1): 39-48.

15. Kulkarni G.P. (2003). Investigations on bacterial wilt resistance in tomato. Ph.D. Thesis, Univ. Agric. Sci., Dharwad.

16. Kulkarni G.P. (2003). Investigations on bacterial wilt resistance in tomato. Ph.D. Thesis, Univ. Agric. Sci., Dharwad.

17. Kumar Y.K.H., Patil S.S., Dharmatti P.R., Byadagi A.S., Kajjidoni S.T. and Patil R. (2009). Estimation of heterosis for tospovirus resistance in tomato. Karnataka Journal of Agricultural Sciences 22(5): 1073-1075.

18. Kumari N., Srivastava J.P., Singh B. and Deokaran (2010). Heterotic expression for yield and its component in tomato (Lycopersicon esculentum Mill.). Annals of Horticulture 3(1):98-101.

19. Kumari S. and Sharma M.K. (2011). Exploitation of heterosis for yield and its contributing traits in tomato (Solanum lycopersicum L.). International Journal of Farm Sciences 1(2): 45-55.

20. Larson R.E. and Currence T.M. (1944). The extent of hybrid components and fruit charaters in tomato. Journal of Tropical Agriculture 39(1): 5-8.

21. Legon M.C., Diaz N. and Perez G.C. (1984). Performance of tomato hybrids and their parents in Summer. Centro Agrocola 11(1): 35-44.

22. Mahendrakar P. (2004). Development of F1 hybrids in tomato (Lycopersicum esculentum Mill.). M.Sc. (Agri.) Thesis, Univ. Agric. Sci., Dharwad.

23. Mirshamssi A., Shahriari M.F. and Nemati H. (2006). Estimation of heterosis and combining ability for yield components and crossing method. Agricultural Sciences and Technology 20(3): 3-12. 
24. Nadarajan N.\& Gunasekaran M. (2012) Quantitative Genetics and Biometrical Techniques in Plant Breeding, Kalyani Publishers.

25. NHB (2013). Handbook of Indian Horticulture Database, NHB, Gurgaon, Haryana, India.

26. Power L. (1945). Relative yield of inbred line and F1 hybrids in tomato. BotGaz 106: 247-268.

27. Prashanth H. (2004). Heterosis and combining ability analysis for higher lycopene content in tomato. M.Sc. (Agri.) Thesis, Univ. Agric. Sci., Dharwad.

28. Pujari C.V. and Kale P.N. (1994). Heterosis studies in tomato. Journal of Maharashtra Agricultural University 19(1): 83-85.

29. Rani C.I. and Veeraragavathatham D. (2008). Studies on heterosis in root knot nematode (Meloidogyne incognita) resistant hybrids in tomato (Lycopersicon esculentum Mill.). The Asian Journal of Horticulture 3(1): 40-44.

30. Rick C.M. (1965). Cytogenetics of the tomato. Advances in Genetics 8: 267-382.

31. Sajjan M.N. (2001). Heterosis, combining ability, RAPD analysis and resistance breeding for leaf curl virus and bacterial wilt in tomato (Lycopersicon esculentum Mill.). M.Sc. (Agri.) Thesis, Univ. Agric. Sci., Dharwad.

32. Sharma D. and Thakur M.C. (2008). Evaluation of diallel progenies for yield and its contributing Traits in tomato under mid hill conditions. Indian Journal of Horticultural Sciences 30(3- 4): 236-238.

33. Singh A., Singh P.K., Dixit J. and Gautam J.P.S. (1995). Heterosis and inbreeding depression in tomato. The Horticultural Journal 8(2): 125-129.

34. Singh A.K. and Asati B.S. (2011). Combining ability and Heterosis studies in tomato under bacterial wilt condition. Bangladesh Journal of Agricultural Research 36(2): 313-318.

35. Singh B., Kaul S., Kumar D. and Kumar V. (2010). Combining ability for yield and its contributing characters in tomato. Indian Journal of Horticulture 67(1): 50-55.

36. Singh C.B., Rai N., Singh R.K., Singh M.C., Singh A.K. and Chaturvedi A.K. (2008). Heterosis, combining ability and gene action studies in tomato (Solanum lycopersicum L.). Vegetable Sciences 35(2): 132-135.

37. Singh N.B., Shabir W.H., Haribhushan A. and Nongthombam R. (2012). Heterosis Studies For Yield and Its Components in Tomato (Solanum lycopersicum L.). VEGETOS 25(2): 257-265.

38. Thakur A.K., Kohil U.K. and Joshi A. (2004). Evaluation of diallel progeny and heterosis for yield and yield contributing components in tomato. Haryana Journal of Horticultural Sciences 33(1- 2): 106-108.

39. Vavilov N.I. (1951). The Origin variation immunity and breeding of cultivated plant. Chronological Botanica 13: 364 .

40. Wellington R. (1912). Influence of crossing in increasing the yield of tomato. Bulletin New York Agriculture Experiment Station 346:67-76.

41. Yashavantakumar K.H. (2008). Heterosis and combining ability for resistance against tospovirus in tomato (Solanum lycopersicon Mill.). Wettsd. M.Sc. (Agri.) Thesis, Univ. Agric. Sci., Dharwad. 